\title{
ALLIUM HOOKERI, Thw. Enum. A LESSER KNOWN TERRESTRIAL PERENNIAL HERB USED AS FOOD AND ITS ETHNOBOTANICAL RELEVANCE IN MANIPUR
}

\section{Ayam VS ${ }^{1^{*}}$}

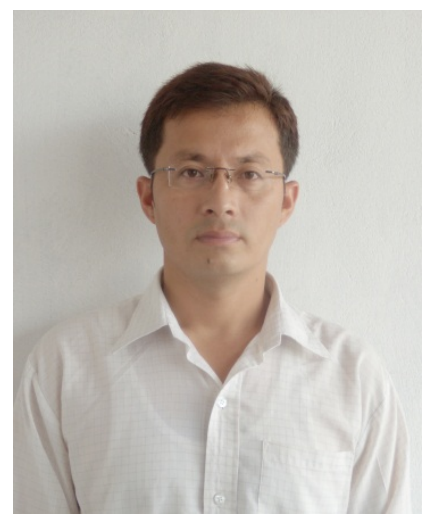

Victor Ayam

*Corresponding author email: victor_ayamsingh@yahoo.com

${ }^{1}$ Department of Botany, Rajiv Gandhi University, Rono Hills, Doimukh, Itanagar, Arunachal Pradesh-791112, India. 


\section{ABSTRACT}

Manipur, one of the north-eastern states of India, is rich in plant diversity and the natives of Manipur have ethnobotanical and traditional knowledge of plants. The rich traditional knowledge of plants is the outcome of a number of hit and trial selections of plants from the wilderness, for consumption and traditional healing of various ailments. In spite of the risk of selection, the diverse food plants provide the required nutrient supplements; as a result deficiency or malnutrition related diseases were uncommon with the Manipuris. Almost all the world renowned sportspersons of Manipur come from poor families who depend on the traditional and indigenous food plants. Many of the plants act as important nutraceuticals, possessing the medicinal properties. Today, due to over exploitation and under production of indigenous food plants, the lifestyles of the people are changed and they prefer 'junk foods'. Subsequently, the health of the people is deteriorating as the indigenous/traditional food plants are neglected at large. The plant is used as spice/condiment in dry or in fresh form in every household in almost all the traditional dishes. It acts as a good supplementary food, providing food security at the household level and help at the time of food crisis. The cultivation of this wild plant (now cultivated to a limited extent) not only generates income for the growers but also helps in the conservation of the plants and their germplasm. In spite of the immense use, Allium hookeri cultivation and its preservation has been decreased due to lack of research-based information of the plant, and due to the concept that wild/traditional plants are poor in nutrition and meant only for the poor. Moreover, agriculturalists and farmers take interest in the cultivation of only the high yielding few cash crops and vegetables. From the result of biochemical analyses, the field survey report and the information from literature, it is known that the plant is fit for consumption and has ethnobotanical relevance. The result of the survey in the urban markets and the rural vendors shows

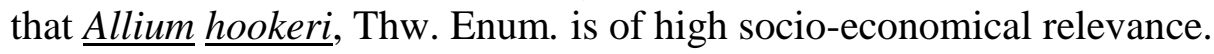

Key words: nutrition, farmers, vegetables, rural, rhizome 


\section{INTRODUCTION}

Manipur, one of the north-east states of India (Fig.1), known for its diverse flora is the home of many indigenous wild food plants. The study site, Manipur, lies at the border area of India and Myanmar.

Mixed populations of Meitei (Major Community), Meitei Brahmins, tribal (twentynine legally accepted tribes), Meitei panghals and Nepalese inhabit the state. The ethnic communities (Manipuri) inhabiting the state use wide varieties of wild plants about 400 species, ranging from algae to angiosperms as food [1]. Allium hookeri, Thw. Enum. of Liliaceae family, locally known as "maroi napakpi" is a wild herb growing in a wide range of soils. Unlike onion or any other Allium species, $\underline{A}$. Hookeri has hardly any bulb; instead a much reduced underground rhizome produces fibrous roots [2]. The leaves of $\underline{A}$. hookeri are thick evergreen, linear with prominent midribs, basal leaves membranous, and shorter than the tall subtrigonous scape. Edible parts of $\underline{A}$. hookeri are different from onion, and instead of the fleshy scale leaves born on the axils of the underground reduced stem (bulb) of onion, the thick, flat, green leaves with prominent midrib and the white fibrous roots represent their edible parts. At present, the cultivation of the plant has started at small scale in the fields, kitchen garden and as pot-herbs for a sustainable food security. This plant was once recognized as one of the vegetable items, condiments/spices of daily importance in all the Manipuri households. The taste and aroma of this plant has been preferred over the use of onion in the preparation of recipes by the family members irrespective of the family income, age and sex. Since $\underline{A}$. hookeri has been associated with the traditional recipes of meiteis and also with the ethnotherapy of certain diseases by local healers since the time immemorial, the plant has been regarded as ethnobotanic relevance to the Manipuris. The objective of the study is to generate detailed information on the mode of consumption and the types of recipe preparation of Allium $\underline{\text { hookeri }}$ and study their market potential. To carry out the quantitative and qualitative phytochemical analysis of the edible parts of A. hookeri and compare its nutritional values with the common vegetable like onion. In developing countries, lesser known plant species are used as food, many of which are not cultivated but gathered from natural habitats and several of these plants are reported to have medicinal properties [3]. The present study helps to introduce Allium hookeri as a supplementary food and as a better substitute of the famous vegetables like onion. The indigenous food constitutes a group of foods that are produced in homes, and villages at prices within the means of the majority of the consumers constituting the developing world. Examination of these foods may, therefore, provide clues as to how food production can be expanded and thereby contribute to improved nutrition in the developing world in the future [4]. Traditional food plants have numerous advantages, especially in terms of household food security. In addition to broadening the food base, they increase the food supply and add variety to the diet [5]. Allium hookeri is also available in the Himalayan range including Nepal, China [6]. 


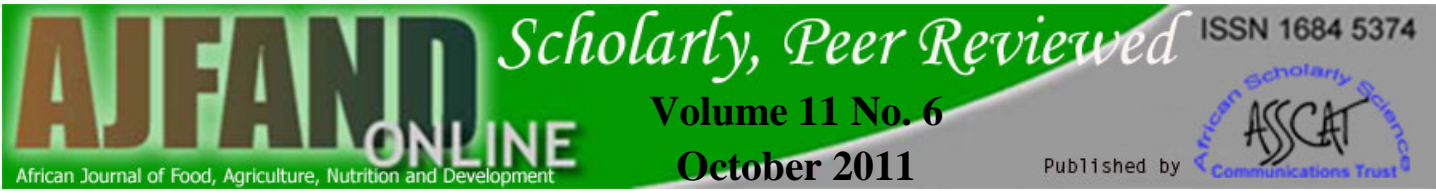
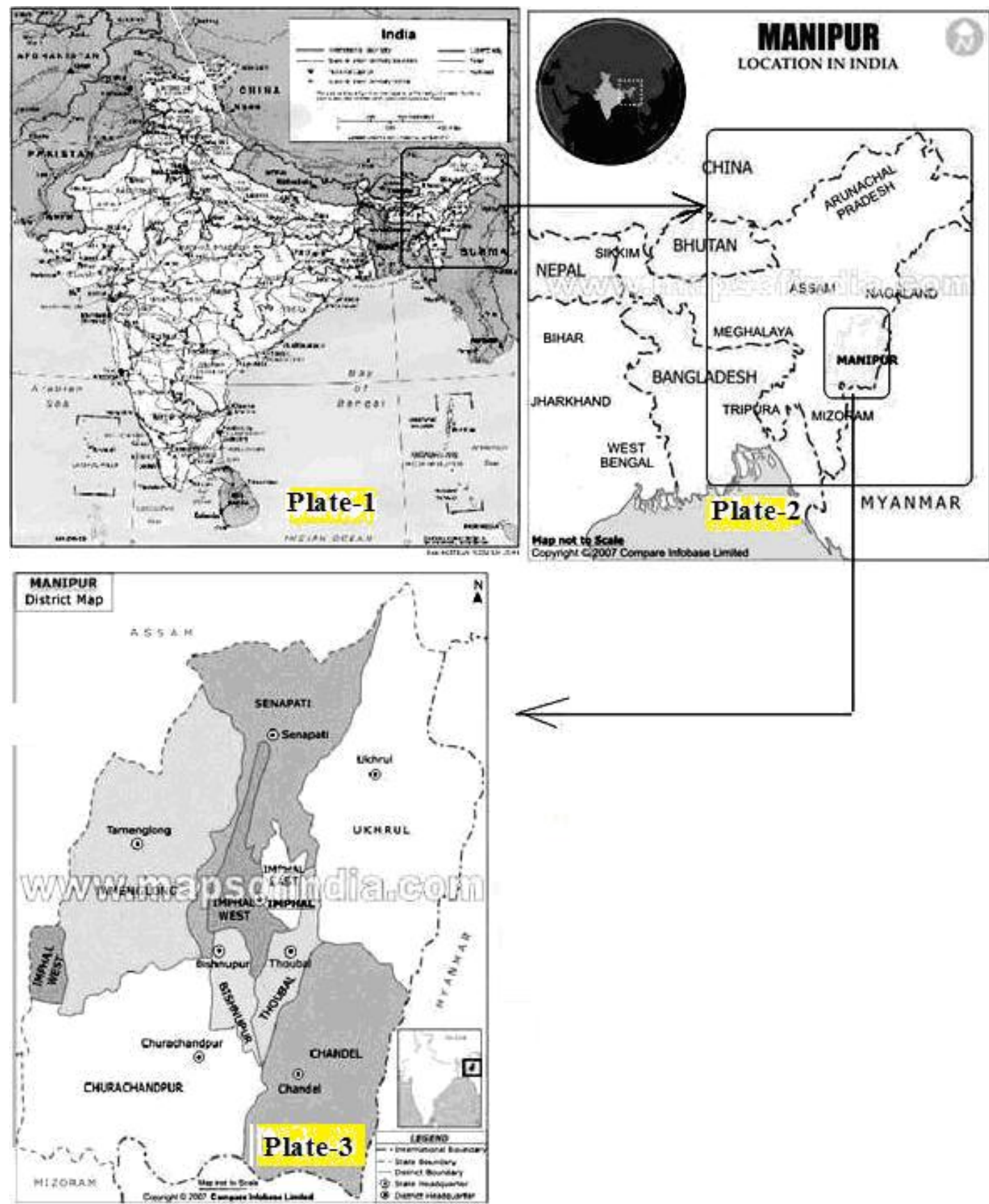

Plate-1: MAP OF INDIA.

Plate-2: MAP OF NORTH-EASTERN STATES.

Plate-3: MAP OF MANIPUR.

\section{Fig-1.-LOCATION MAP OF MANIPUR(Study site)}

Though the plants are grown in other places, they are treated as ornamental plants or weeds as their utilization is not known to them, which otherwise are socioeconomically important. Plants are either gathered from the wild or collected from the 
fields by the farmers and sold to the agents in the main markets of the plain districts of the state, who act as the wholesalers who then sell to the retailers who in turn sold it to the sub-retailers. In the larger markets of the hill districts, collected plants are sold by farmers to retailers, which are then sold at retail prices to sub-retailers, who in turn sell it to customers and wholesalers were absent. In smaller markets farmers sold them at sub-retail prices and wholesalers and retailers are absent. A. hookeri are preserved at households by sundry method and parcelled to students and relatives who stay outside the state. Thus, indicating the possibility of marketing even to the areas where the natural growth does not occur. For the authenticity and fitness as a supplementary food, the detailed analyses of the nutritional parameters of the edible parts (leaves and roots) were carried out in terms of biochemical estimates. The analysis includes quantitative estimation of starch, total soluble sugar, reducing and non reducing sugars, total phenol, phytosterols, total protein, total amino acids, varying quantities of different types of amino acids, total fat, ascorbic acid, total nitrogen, soluble and insoluble nitrogen, moisture and dry matter percentage. Since Allium hookeri plays a major role as a food substitute, providing food security and supports many families financially, the analysis of its market potential was considered essential and the survey of local markets and villages was conducted.

\section{MATERIALS AND METHODS}

\section{Location of study site:}

The study site comprises the nine districts of Manipur, one of the North-Eastern States of India surrounded by the neighboring states like Nagaland, Assam and Mizoram and is situated at the border area with Myanmar as its immediate neighbor. The state is located at $93.03^{\mathrm{O}} \mathrm{E} \& 94.78^{\mathrm{O}} \mathrm{E}$ longitude, $23.83^{\mathrm{O}} \mathrm{N}$ \& $25.68^{\circ} \mathrm{N}$ latitude and altitude of 781 to $2020 \mathrm{~m}$ from the sea level. Out of the total of nine districts, four are in valleys such as Imphal West, Imphal East, Thoubal, Bishenpur, which is surrounded by the remaining five hilly districts namely, Senapati, Ukhrul, Tamenglong, Chandel, and Churachandpur. A. hookeri is found more in the valley district, which is at $790 \mathrm{~m}$. altitude, between $93.42^{\mathrm{O}} \mathrm{E}$ to $94.47^{\circ} \mathrm{E}$ longitude and between $23.83^{\mathrm{O}} \mathrm{N}$ to $25.41^{\mathrm{O}} \mathrm{N}$ latitude and comprises of an area of $2238 \mathrm{sq}$. km, which is $10 \%$ of the total area and the remaining $90 \%$ comprises of hills [7].

Ethnicity of the study site: Populations in hills and valley comprise $36 \%$ and $64 \%$, respectively of the total population of state of Manipur. Meiteis, the valley dwellers, are the major community with a population of $13,61,521$ out of the total population of 23, 88,634 of the state as per 2001 Census [8, 9, 10]. The other minorities are namely: Muslims (riverbed dwellers), Nepalies (hill dwellers) and 29 legally recognized tribes with 16 unrecognized minor tribes (hill dwellers). Different communities have different dialects but a common communication language is meiteilon, the mother tongue of the major community, meiteis. 
Survey and collection of information on the utility and ethnomedicinal importance of the plant:

Information on the use and utility of Allium hookeri, as food and medicine was generated through household survey and personal interaction with the local people in rural and urban areas of Manipur during January, 2009-11. The details of the indigenous recipes of Allium hookeri and the methods of preparation were then recorded and tabulated (Table 1 ). Female members of the families especially the housewives, mothers and female elders were the most important respondents during the survey as they are the ones engaged in daily cooking and kitchen works who could tell about the recipes. The recipe components of daily consumption and the frequencies of consumption were recorded (Table 2). The leaves' juice with salt is also used as a source of medicine to cure ulcer and stomach ailments by the local healers. The leaf decoction (Decoction is a method of extraction, by boiling, or dissolved chemicals, or herbal or plant material, which may include stems, roots, bark and rhizomes.) paste is applied on forehead in reducing excessive body temperature and blood pressure [11].

Analysis of edible parts of $A$. hookeri:

Plants were collected from the natural habitats and markets of the study sites for the phytochemical analysis. Unlike onion, A. hookeri have no bulb and the edible parts were represented by the thick, green, flat, linear leaves and the fibrous roots both born on rhizome. The rhizome is negligibly small with a length of $1-2 \mathrm{~cm}$ and a thickness of 3-4 $\mathrm{mm}$ and is without any peculiar taste; hence, it is not considered as an edible part, though sometimes it is taken along with the roots. The edible parts (leaves and roots) were analyzed using different analysis methods and the quantities present were recorded (Table 3). Carbohydrates were determined using: i) Anthrone method [12] for the estimation of total soluble sugars (TSS), ii) Nelson's method for estimation of reducing sugars [13] (RS), iii) methods of Malhotra and Sarkar for non-reducing sugars according [14] and iv) the Anthrone method derived from i) for the estimation of total starch. (TS). Total fat (TF) was determined using the method of Leslie and Fisher [15], the Ninhydrin method [16] was used for estimation of total amino acids (TAA), qualitative analysis of the individual amino acids was with the Thin Layer Chromatography method [17], and the elution technique for quantitative estimation of individual amino acids. Total nitrogen (TN) was determined with the micro-Kjeldahl method and soluble and insoluble nitrogen (SNF, INTF) using the method of Lang [18]. Ascorbic acid content was determined with the indophenol reduction method [19]. Total phenol was determined with the Folin-Ciocalteu's method [20] and total phytosterol (TPS) with the Libermann-Burchard reaction method [21]. Moisture content was determined according to the AOAC methods [22].

Comparison of some of the important nutritional components of $A$. hookeri with A. cepa: USDA nutrient database of onion [23] is compared with that of the $A$. hookeri (Table 4).

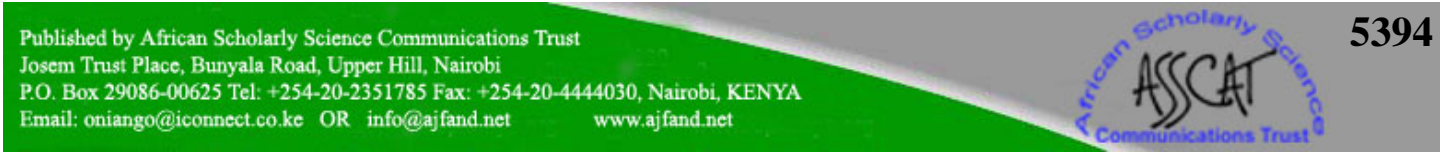




\section{Study of the market potential of $A$. hookeri:}

The market potential of Allium hookeri was determined after a survey of wholesalers, and retailers (vendors) in different urban and rural markets of the state, during the luxuriant growth period (April to June), during 2009-2011 (tables 5, 6 \& 7). The results of the survey were analysed for determining the socio-economic relevance of the plants.

\section{RESULTS}

Table 1 shows the type of recipes of Allium hookeri and their modes of preparations as cited by the respondent households. The frequencies of utilization of the recipes are expressed based on the number of respondents that cited a particular recipe, out of the 450 households that were interviewed in the 9 districts of Manipur. Only the recipes cited by more than $50 \%$ of the respondents are tabulated. From the table, the parts utilized were known to be the green aerial leaves and the associated underground white rhizomes (Fig.2). 


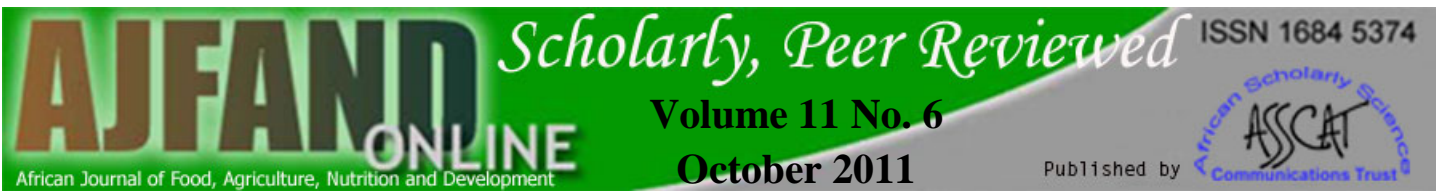

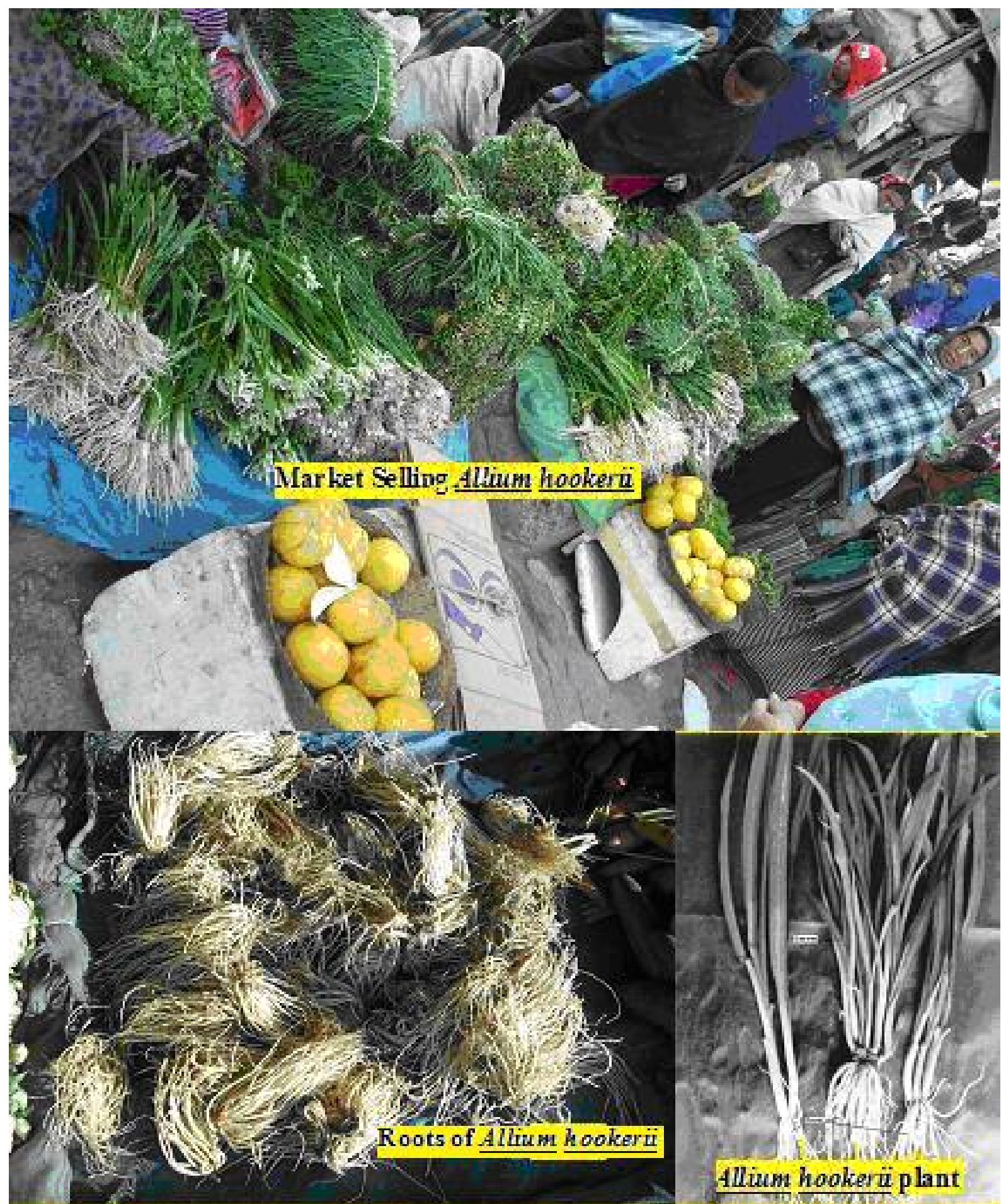

Fig.2: Photos of one of the vegetable markets selling Allium hookeriu and show ing the edible $p$ arts of the $p$ lant $p$ arts

Figure 2: Photos of a vegetable market selling Allium hookeri in Manipur and showing their edible parts.

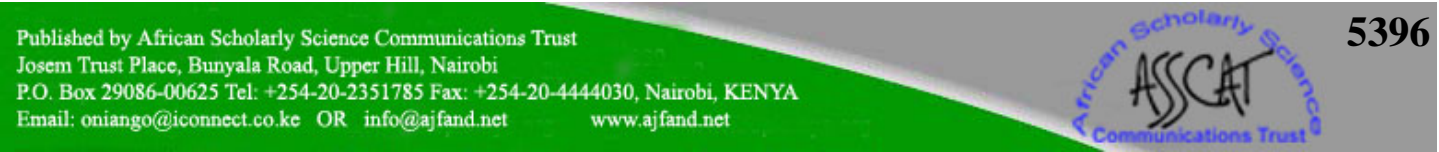




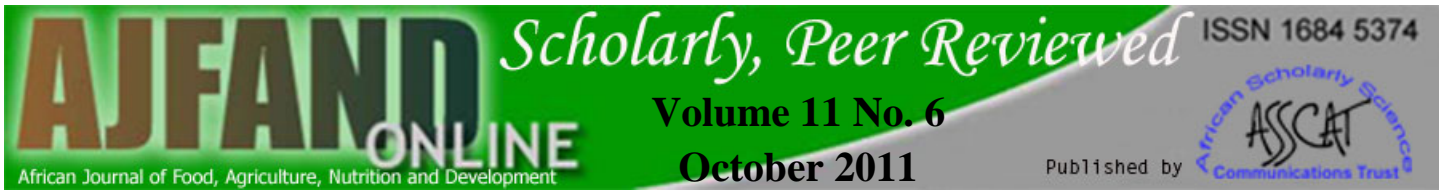

Table 2 shows the frequencies of daily consumption of the recipes among the respondent households which were grouped into three broad categories, namely, rarely consumed (consumed less than 2 times a week) and often consumed (consumed 2 to 4 times a week), very often consumed (consumed more than 4 times a week). The frequencies of consumption of the different recipes were compared by applying a weight of 1, 2 and 3 to the frequencies for "rarely", "often" and "very often", respectively, to obtain the composite score, which was used to compute a mean score. Table 3 shows the quantitative nutritional contents of leaves and roots of $A$. hookeri, namely, total sugar, reducing sugar, non-reducing sugar, starch, total nitrogen, soluble and insoluble nitrogen, total crude protein, total amino acids, different amino acids composition, total fat, total phenol, total phytosterols, vitamin C, fibre percentage and moisture percentage obtained by the different biochemical analysis methods. The differences in the quantities between the leaves and the rhizomes are significant at $\mathrm{p} \geq 0.05$. Amino acids, namely, aspartic acid, threonine, valine, phenylalanine and tryptophan are present only in the leaves; whereas alanine, histidine and nor-leucine only are in rhizomes while methionine, glycine and lysine occur in both (Figures 3 \& 4).

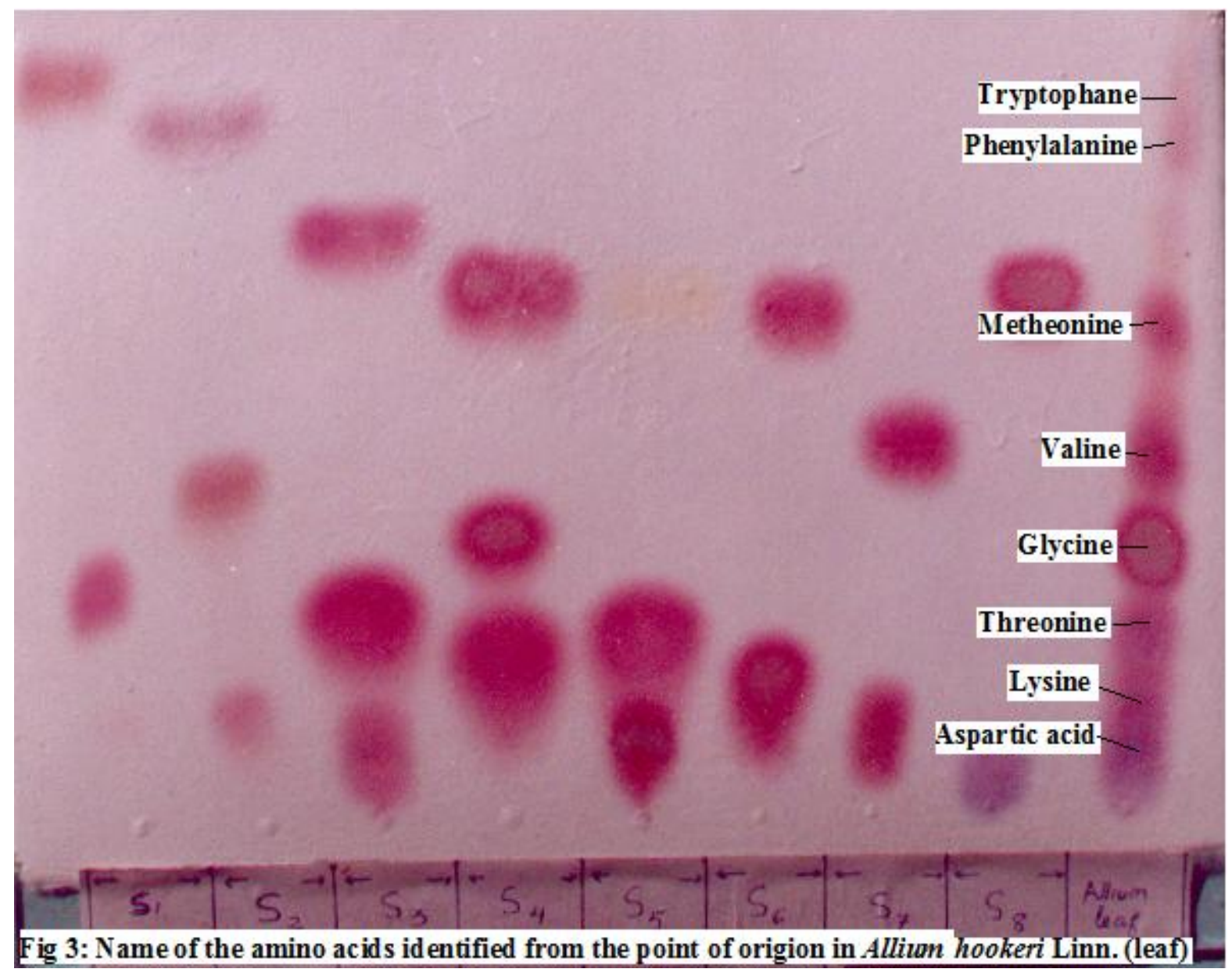

Published by African Scholarly Science Communications Trust Josem Trust Place, Bunyala Road, Upper Hill, Nairobi 


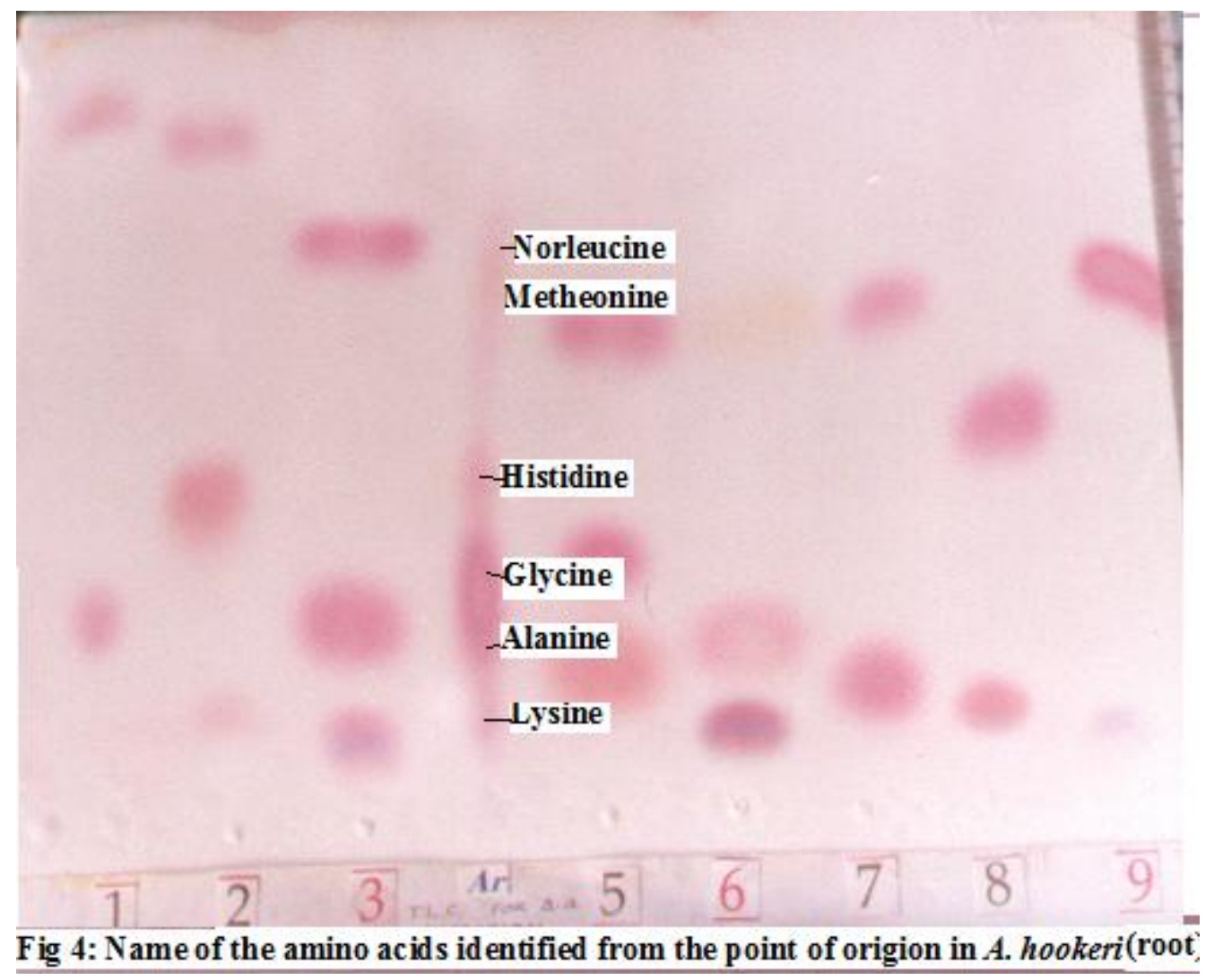

Table 4 shows the amount of total protein, sugar, fibres, ascorbic acids and total phytosterols in A. Hookeri. These amounts are higher than those in of $A$. cepa. The

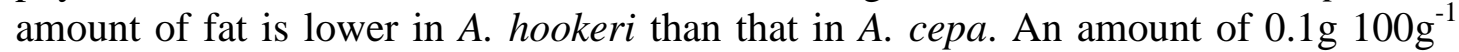
dry wt. (0.1\% of the dry weight) of total phytosterols is present in A. cepa [24].

Tables 5 and 6 show market scenarios of Allium hookeri in the plain and hill districts of Manipur. The tables also show the wholesale and retail prices of the plant, quantities sold and the total sale prices per day during its peak period (April-June). Plants gathered/collected from the wild/fields are sold to agents (wholesalers) in the main markets, which are then sold to the retailers at wholesale rate, which are in turn sold at retail prices. The prices shown were the mean of 20 separate days of observations of the markets and vendors during the normal and luxuriant growth periods. The tables as a whole show the generation of income from this plant in the households.

Table 7 shows the daily Profit of wholesalers, retailers and sub-retailers (vendors) in the plain and Hill districts of Manipur from Allium hookeri. 


\section{DISCUSSION}

A list of seven recipes of Allium hookeri, the ingredients required, the methods of preparation and the frequencies of consumption by the Manipuris was prepared based on a survey carried out in the 450 households, covering the nine districts of Manipur (table1). Generally the recipes are prepared by frying, steaming, baking and boiling which are all popular with slight differences in frequencies of consumption. Over 84.44\% households prepared by steaming/baking (maroi napakpi paknum), 68.89\% by deep-frying (maroi napakpi bora), other recipes were consumed as maroi napakpi nganum (64.44\%), maroi napakpi kangsoy (62.22\%), maroi napakpi yerum tal (55.55\%) and over $48 \%$ are consumed by deep frying with boiling (Maroi napakpi pakoura). A maximum consumption of $98.89 \%$ is in the form of spices and condiments in almost all the households. The frequencies of consumption of the recipes show the importance of the plant for household food security (Table 2). The recipes tabulated are popular in grand feasts, traditional ceremonial feasts, parties and are also popularly sold in hotels and restaurants. Thus, this indigenous/traditional food plants not only provide the food security and dietary diversity but also help to generate income in the households.

Allium hookeri contains higher amounts of total protein, sugar, fibre ascorbic acid, phytosterols and total phenols with the lower amount of total fat than A. серa. The presence of higher amount of protein, ascorbic acid and lower amount of fat is a character of healthy food. Moreover, presence of higher concentration of total phytosterols $(0.5 \mathrm{~g} / 100 \mathrm{~g}$ fresh weight) and containing a good amount of total phenols (2g.100g ${ }^{-1}$ dry wt.) (Table 4) is another character of healthy food. Apart from its nutritional contents $A$. hookeri have the better taste and aroma, so can be treated as a better substitute of onion and a worthy supplementary vegetable, spice and/or condiment. In spite of the popularity and high demand, the use of this plant is slowly decreasing due to overexploitation and under cultivation. Phenol and phytosterol which are of very high price in the global markets for their medicinal properties were rich in Allium hookeri. The therapeutic benefits of fruits, vegetables, tea and wine are mostly attributed to the presence of phenolic compounds [25]. Percentage intestinal cholesterol absorption decreased with increasing phytosterol intake, resulting in a decrease in dietary cholesterol absorption [26]. Phytosterols can significantly lower serum LDL cholesterol concentrations at about $10 \%$ when consumed at the recommended dose of $2 \mathrm{~g} / \mathrm{d}$ [27]. Phytosterols are used as an efficient cholesterol lowering agent in various food products [28]. Phytosterols are safe when added to the diet, and measured absorption and plasma levels are small. Increasing the aggregate amount of phytosterols consumed in a variety of foods may be an important way of reducing population cholesterol levels and preventing coronary heart disease [29]. According to $\mathrm{Wu}$ et al.[30] plant flavonoids are polyphenolic compounds and at nontoxic concentration, considered for increasing efficacy in drug therapies. A higher flavonoid (polyphenolics) intake correlates with a lower incidence of coronary heart disease (CHD) [31]. Phenolic antioxidant inhibits the radicals and significantly decreases the adverse effects on normal physiological functions in humans. The phenolic plant extract can be used in the production of food supplements and cosmetic products [32]. Several studies proved that the total phenolics content was highly

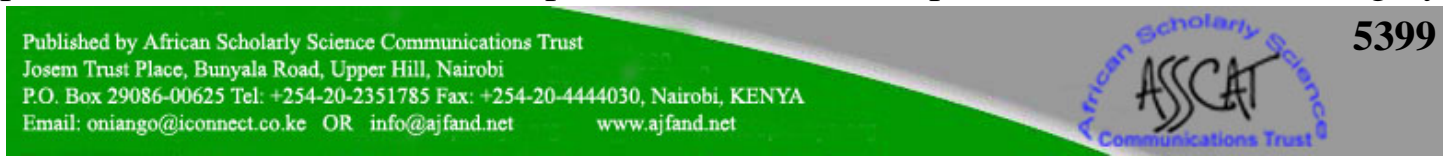


positively correlated with antioxidant activity [33]. The efficacy of phytosterols appears to function independently of dietary fat; thus, there has been a movement to incorporate phytosterols into low-fat foods in order to promote a low-fat, low cholesterol diet profile to further improve health lipid profiles [34]. Ethyl acetate extracts of Allium hookeri present the best antimicrobial activity [35]. A. hookeri, having high phytosterol, phenols, ascorbic acid and fibre and low fat could be treated as a healthy food. From the information of traditional healers and literature, this plant, while consuming as vegetable also reduces blood pressure, stomach ulcer and excessive body temperature. Therefore, Allium hookeri could be used as a supplementary food, which simultaneously protects the body from certain diseases. The result of analysis shows upto $6625 \pm 610 \mathrm{~kg} \cdot \mathrm{day}^{-1}$ of Allium hookeri is sold by the plant gatherers at an average price of Rs. $80 \pm 5 / \mathrm{kg}^{-1}$ amounting to a total of Rs.533050 \pm 81925 to the wholesalers, which was in turn sold at an average wholesale price of Rs. $88 \pm 5 / \cdot \mathrm{kg}^{-1}$ to retailers amounting to a total of Rs.586050 $\pm 86805 \cdot / \mathrm{day}^{-1}$. The retailers in turn sold at an average price of Rs. $110.15 \pm 5 / \mathrm{kg}^{-1}$ to the sub-retailers and consumers in the valley markets amounting to a total of Rs. $729150 \pm 110588 /$ - day ${ }^{-1}$. A total amount of $722 \pm 157 \mathrm{~kg} \cdot \mathrm{day}^{-1}$ of $A$. hookeri are bought by sub-retailers from retail markets as well as from the kitchen garden growers at the rate of Rs. $109.62 \pm 5 \cdot \mathrm{kg}^{-1}$ with a total cost price of Rs.79775 $\pm 20760 \cdot$ day $^{-1}$ which were sold at the sub-retail price of Rs. $125.03 \pm 5 \cdot \mathrm{kg}^{-1}$ amounting to a total sub-retail price of Rs.91001 $\pm 23212 \cdot$ day $^{-1}$ by sub-retailers in the markets of plain districts of Manipur. Thus, the farmers (plant gatherers/suppliers) earn a net daily profit of Rs.533050 \pm 81925 on Allium hookeri from the markets of the plain districts of Manipur (this does not include the small income from selling A. hookeri of their kitchen garden to smaller vendors at sub-retail prices). The net daily profits of the wholesalers, retailers and sub-retailers are Rs. $53000 \pm 4880,143100 \pm 13120$ and $11226 \pm 2452$, respectively, from the valley markets.

In the markets of the hilly districts, farmers/plant gatherers either collecting from wild or from their kitchen garden, and supplies to retailers which are in turn sold to subretailers. Sub-retailers bought $A$. hookeri from both the retailers and farmers at different prices, and there were no wholesalers. An amount of $600 \pm 100 \mathrm{~kg}$ of Allium hookeri bought at Rs. $88 \pm 5 \mathrm{Kg}^{-1}$ from the farmers by retailers, are sold at Rs.112 \pm 5 $\cdot \mathrm{kg}^{-1}$ and an average amount of $373 \pm 28 \mathrm{~kg}$ of Allium hookeri bought at Rs. $112 \pm 5 \mathrm{Kg}^{-1}$ both from the retailers and farmers by sub-retailers, are sold at Rs. $130 \pm 5 \cdot \mathrm{kg}^{-1}$ in the markets of the hill districts. The total sale price of the retailers and sub-retailers day ${ }^{-1}$ are Rs. $67700 \pm 14200$ and Rs. $48630 \pm 5505$, respectively. Therefore, net daily Profits of the retailers and the sub-retailers of Allium hookeri from the Markets of the Hill districts of Manipur are Rs. $14400 \pm 2400$ and Rs. $6714 \pm 499$, respectively. The farmers (plant gatherers/suppliers) earn a net daily profit of Rs. $83981 \pm 15517$ from the markets of the Hill districts of Manipur. Therefore, the net daily profit obtained from

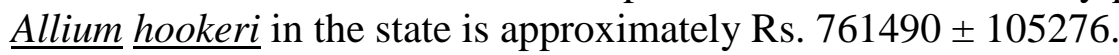




\section{CONCLUSION}

The present study documents the Meiteis recipes of Allium hookerii, popular among the Manipuris. The nutritional values and medicinal properties of A. hookeri determined, through analysis and from the literature to study the fitness of the plant as a supplementary food. In the course of the survey, it was found that the plant is used in seven different forms, frequently in more than $50 \%$ of the households that were surveyed. Thus, the level of utilization of the plant is high and has the potential for agricultural and commercial exploitation. From the analysis, it was determined that $A$. hookeri is a good source of various nutrients and is a better source of sugars, phenol, phytosterols, Vitamin C, fibre and protein than A. cepa, while at the same time having lower amount of fat than onion suggests it is a better substitute (table 4). In spite of the food security and financial support provided by Allium hookeri at the household levels, the rate of gathering, domestication and consumption is declining in the state. The factors responsible for the decline may be highlighted as the following:-

- Farmers are interested in the cultivation of cash crops instead of the indigenous food plants for earning income; as such the plant has not been given the chance to prove its worth.

- Decline in gathering of the plant and its domestication are due to the limited knowledge of the nutritional compositions and medicinal properties to the farmers, and largely due to emphasis given, on commercial, high yielding plants even by the agriculturalists.

- With the increasing population and expansion of the settlement area, portions of the forests and swamps are encroached, and habitats are used for the cultivation of the already known more aggressively promoted cash crops.

- Due to lack of conservation policy and due to the wrong belief, that local and indigenous plants are less nutritious and only fit for consumption by the poor communities. Moreover, with the changing lifestyle, people prefer "junk foods" which take lesser time for preparation, and are believed to possess better nutrition.

Realizing the requirement of researched knowledge about the nutritional and health values of indigenous food plants, in changing the attitude of agricultural workers and the rural communities, for saving the indigenous food plants from a possible loss, the present study was conducted. Research analyses proved that these food plants are worthy of consumption and should therefore be categorized as healthy food. During the survey, it was also found that many of the households and also the state were financially supported by the plant; hence, the plant has socio-economic relevance. 


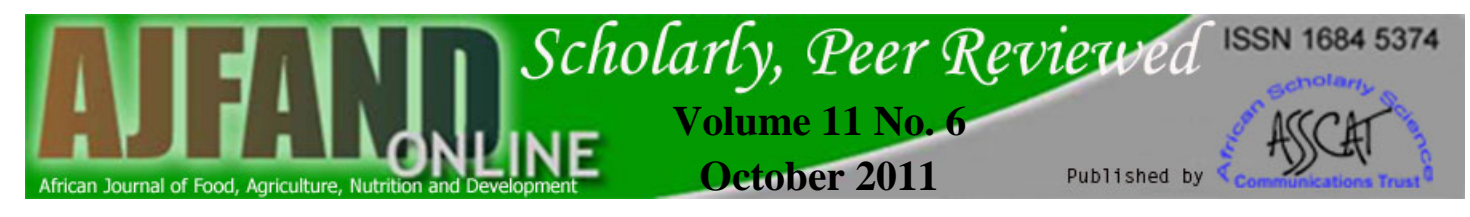

Table 1: Some of the food recipes of Allium hookeri recorded and documented

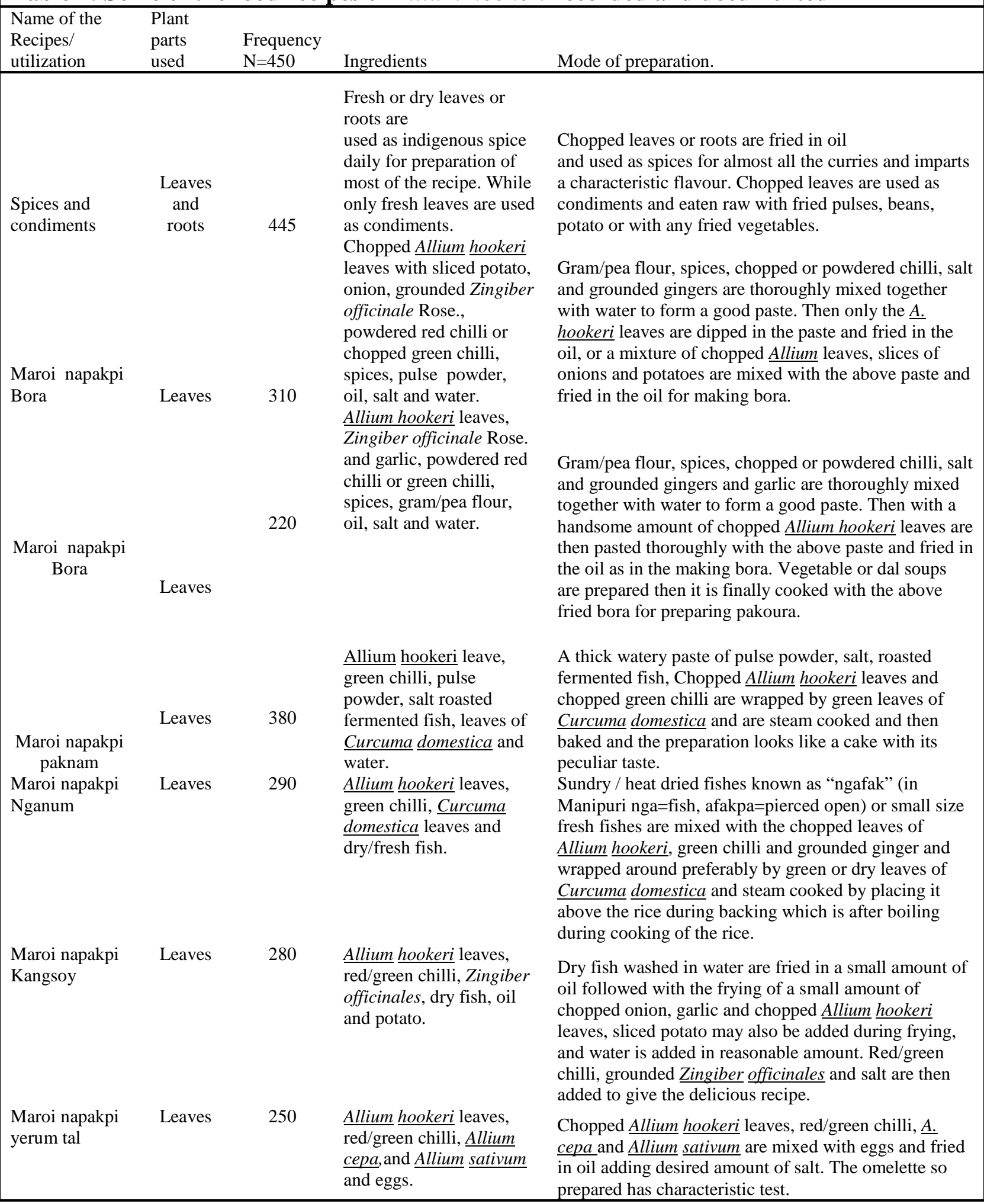

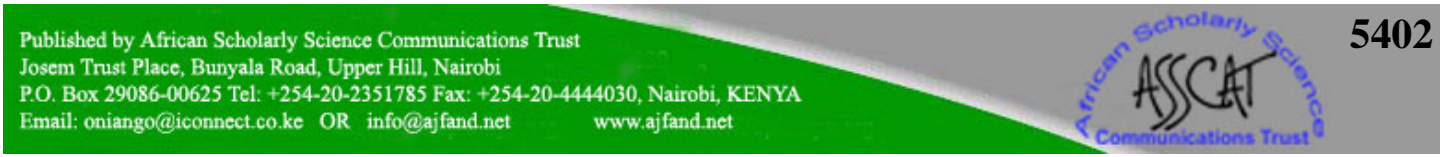




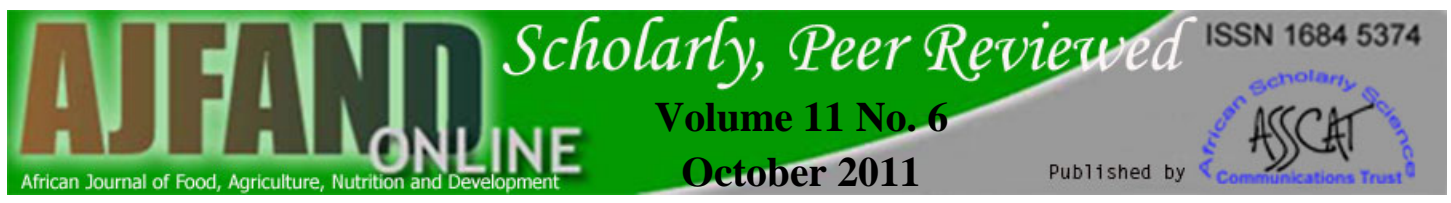

\begin{tabular}{|l|l|c|c|c|c|c|}
\hline \multicolumn{2}{|l|}{ Table 2: Frequency of consumption of the various types of recipes of Allium hookeri } \\
\hline Name of the Recipes & Frequency & Rarely (x1) & $\begin{array}{l}\text { Often } \\
(\mathrm{x} 2)\end{array}$ & $\begin{array}{l}\text { Very often } \\
(\mathrm{x} 3)\end{array}$ & $\begin{array}{l}\text { Composite } \\
\text { score }\end{array}$ & Mean score \\
\hline Spices and condiments & 445 & 5 & 35 & 405 & 1290 & 2.89 \\
\hline Maroi napakpi Bora & 310 & 20 & 130 & 160 & 760 & 2.45 \\
\hline Maroi napakpi pakoura & 220 & 62 & 80 & 78 & 456 & 2.07 \\
\hline Maroi napakpi paknam & 380 & 90 & 110 & 180 & 850 & 2.24 \\
\hline Maroi napakpi Nganum & 290 & 210 & 70 & 10 & 380 & 1.31 \\
\hline Maroi napakpi Kangsoy & 280 & 90 & 170 & 20 & 490 & 1.75 \\
\hline Maroi napakpi yerum tal & 250 & 80 & 120 & 50 & 470 & 1.88 \\
\hline
\end{tabular}




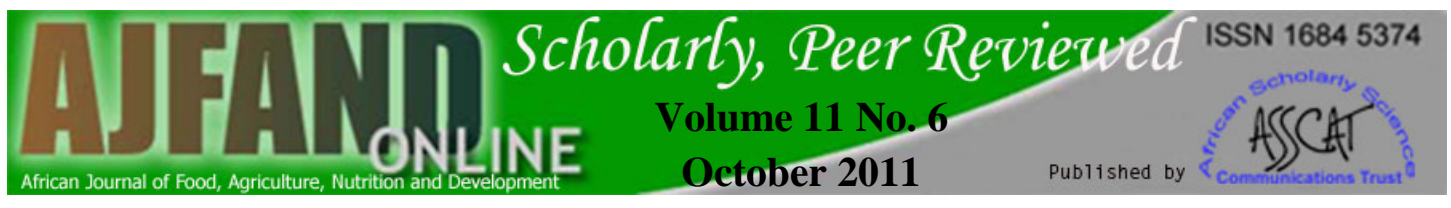

\begin{tabular}{|c|c|c|}
\hline \multicolumn{3}{|c|}{$\begin{array}{c}\text { Table 3:Nutrients in g per 100g dry weight of leaves and roots of Allium hookeri } \\
\text { Mean } \pm \text { standard deviation in } g .100 \mathrm{~g}^{-1} \text { dry wt. }\end{array}$} \\
\hline Parts used & Leaves & Roots \\
\hline Total sugar & $1.10 \pm 0.01$ & $4.31 * \pm 0.04$ \\
\hline Reducing Sugar & $0.18^{*} \pm 0.01$ & $0.004 \pm 0.02$ \\
\hline Non-reducing Sugar & $0.85 \pm 0.03$ & $4.30 * \pm 0.01$ \\
\hline Starch & $0.10 * \pm 0.02$ & $0.09 \pm 0.04$ \\
\hline Total Fat & $0.008 \pm 0.002$ & $0.005^{*} \pm 0.003$ \\
\hline Total nitrogen & $0.20 * \pm 0.02$ & $0.05 \pm 0.01$ \\
\hline Soluble Nitrogen & $0.09 * \pm 0.003$ & $0.005 \pm 0.002$ \\
\hline Insoluble Nitrogen & $0.068 * \pm 0.003$ & $0.014 \pm 0.003$ \\
\hline \multicolumn{3}{|l|}{ Total crude Protein (from total } \\
\hline nitrogen) & $1.25 * \pm 0.04$ & $0.31 \pm 0.02$ \\
\hline Total amino acid contents & $0.13^{*} \pm 0.02$ & $0.16 \pm 0.02$ \\
\hline Total Phenol & $2.00 * \pm 0.04$ & $0.10 \pm 0.030$ \\
\hline Total Phytosterol & $0.50 * \pm 0.01$ & $0.13 \pm 0.02$ \\
\hline Vitamin C & $21 \mathrm{mg}^{*} \pm 0.004$ & $1 \mathrm{mg} \pm 0.006$ \\
\hline Moisture \% & $88 \%$ & $92 \%$ \\
\hline Dry matter \% & $18 \%$ & $8 \%$ \\
\hline Types of Amino acids present & Asp,Lys,Thr,Gly,Val,Met,Phe,Trp, & Lys,Gly,Met,Nor leu,Ala and His \\
\hline
\end{tabular}




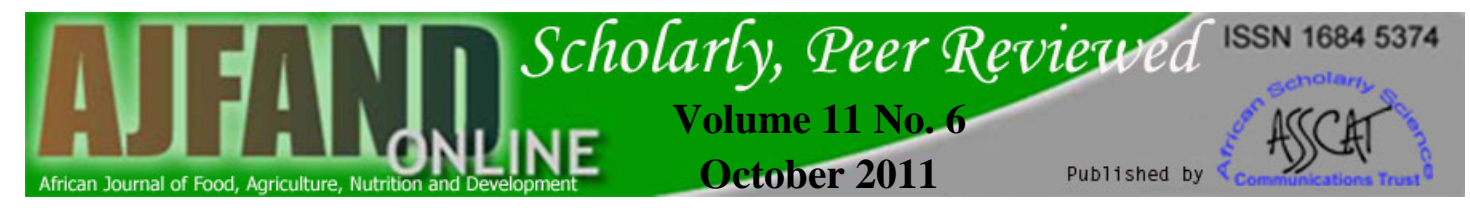

\begin{tabular}{|c|c|c|c|c|c|c|c|}
\hline \multicolumn{8}{|c|}{$\begin{array}{l}\text { Table 4: Comparison of the nutritional contents of } A \text {. hookeri with } A \text {. cepa } \\
\text { amounts in } \mathrm{g} \cdot 100 \mathrm{~g}^{-1} \text { fresh wt. }\end{array}$} \\
\hline $\begin{array}{c}\text { Name of The } \\
\text { Plant }\end{array}$ & Protein & $\begin{array}{l}\text { Total } \\
\text { Sugar }\end{array}$ & Total Fat & Phytosterol & Fibre & Moisture & $\begin{array}{c}\text { Ascorbic } \\
\text { acid } \\
\text { (mg/100g) }\end{array}$ \\
\hline Allium hookeri & 1.25 & 4.31 (root) & $\begin{array}{l}0.005 \\
\text { (root) }\end{array}$ & $\begin{array}{c}0.5 g(0.5 \% \text { of } \\
\text { the fresh } \\
\text { weight) }\end{array}$ & $18 g$ & $88 g$ & $\begin{array}{c}21 \text { mg (fresh } \\
\text { leaves) }\end{array}$ \\
\hline A. сера & 1.1 & 4.24 & 0.1 & $\begin{array}{c}0.1 \mathrm{~g}(0.1 \% \text { of } \\
\text { the dry } \\
\text { weight })\end{array}$ & $1.7 \mathrm{~g}$ & 89.11g & $7.4 \mathrm{mg}$ \\
\hline
\end{tabular}




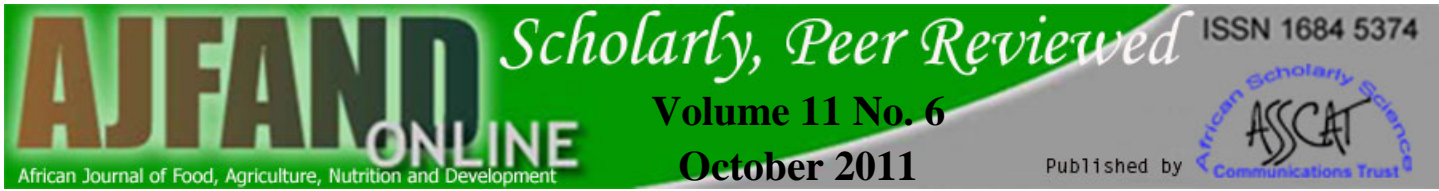

\section{Table 5: Daily Market scenario of Allium hookeri of the wholesale, retail and sub-retail markets of the Plain districts of Manipur in (2009-10).}

\begin{tabular}{|c|c|c|c|c|c|c|c|}
\hline $\begin{array}{l}\text { Name of the } \\
\text { market }\end{array}$ & $\begin{array}{l}\text { Category } \\
\text { of the } \\
\text { Markets }\end{array}$ & $\begin{array}{l}\text { Quantity } \\
\text { Sold day }{ }^{-1}\end{array}$ & $\begin{array}{l}\text { Cost price } \\
\text { in } \mathrm{Rs} . \mathrm{Kg}^{-1}\end{array}$ & $\begin{array}{l}\text { Sale price } \\
\text { in Rs. } \mathrm{Kg}^{-1}\end{array}$ & $\begin{array}{l}\text { Total cost } \\
\text { price in Rs. }\end{array}$ & $\begin{array}{l}\text { Total sale } \\
\text { Price in Rs. }\end{array}$ & $\begin{array}{l}\text { Total income } \\
\text { (profit) in Rs. day }{ }^{-1}\end{array}$ \\
\hline Khwai keithel/ & $\bar{W}$ & $6625 \pm 610$ & $80 \pm 5$ & $88 \pm 5$ & $533050 \pm 81925$ & $586050 \pm 86805$ & $53000 \pm 4880$ \\
\hline Khwairambad Bazaar & $\mathrm{R}$ & $1000 \pm 100$ & $88 \pm 5$ & $102 \pm 5$ & $88500 \pm 13800$ & $102500 \pm 15200$ & $14000 \pm 1400$ \\
\hline Bisnupur & $\mathrm{R}$ & $500 \pm 50$ & $88 \pm 5$ & $115 \pm 5$ & $44250 \pm 6900$ & $57750 \pm 8250$ & $13500 \pm 1350$ \\
\hline Bazaar & SR & $50 \pm 10$ & $115 \pm 5$ & $129 \pm 5$ & $5800 \pm 1400$ & $6500 \pm 1540$ & $700 \pm 140$ \\
\hline Kakching & $\mathrm{R}$ & $600 \pm 50$ & $88 \pm 5$ & $115 \pm 5$ & $53050 \pm 7400$ & $69250 \pm 8750$ & $16200 \pm 1350$ \\
\hline Bazaar & SR & $40 \pm 8$ & $115 \pm 5$ & $129 \pm 5$ & $4640 \pm 1120$ & $5200 \pm 1232$ & $560 \pm 112$ \\
\hline \multirow{3}{*}{ Thoubal Bazaar } & $\mathrm{R}$ & $600 \pm 50$ & $88 \pm 5$ & $112 \pm 5$ & $53050 \pm 7400$ & $67450 \pm 8600$ & $14400 \pm 1200$ \\
\hline & SR & $35 \pm 7$ & $112 \pm 5$ & $126 \pm 5$ & $3955 \pm 959$ & $4445 \pm 1057$ & $490 \pm 98$ \\
\hline & $\mathrm{R}$ & $600 \pm 50$ & $88 \pm 5$ & $112 \pm 5$ & $53050 \pm 7400$ & $67450 \pm 8600$ & $14400 \pm 1200$ \\
\hline Nambol Bazaar & SR & $30 \pm 6$ & $105 \pm 5$ & $128 \pm 5$ & $3180 \pm 780$ & $3870 \pm 918$ & $690 \pm 138$ \\
\hline \multirow[b]{2}{*}{ Khurai Bazaar } & $\mathrm{R}$ & $650 \pm 50$ & $88 \pm 5$ & $110 \pm 5$ & $57450 \pm 7650$ & $71750 \pm 8750$ & $14300 \pm 1100$ \\
\hline & SR & $32 \pm 6$ & $110 \pm 5$ & $126 \pm 5$ & $3550 \pm 820$ & $4062 \pm 916$ & $512 \pm 96$ \\
\hline Singjamei & $\mathrm{R}$ & $650 \pm 50$ & $88 \pm 5$ & $108 \pm 5$ & $57450 \pm 7650$ & $70450 \pm 8650$ & $13000 \pm 1000$ \\
\hline Keithel & SR & $25 \pm 5$ & $108 \pm 5$ & $120 \pm 5$ & $2725 \pm 665$ & $3025 \pm 725$ & $300 \pm 60$ \\
\hline \multirow[b]{2}{*}{ Lilong Bazaar } & $\mathrm{R}$ & $350 \pm 40$ & $88 \pm 5$ & $110 \pm 5$ & $31000 \pm 5270$ & $38700 \pm 6150$ & $7700 \pm 880$ \\
\hline & SR & $27 \pm 6$ & $110 \pm 5$ & $122 \pm 5$ & $3000 \pm 795$ & $3324 \pm 867$ & $324 \pm 72$ \\
\hline Nongmeibung & $\mathrm{R}$ & $650 \pm 50$ & $88 \pm 5$ & $108 \pm 5$ & $57450 \pm 7650$ & $70450 \pm 8650$ & $13000 \pm 1000$ \\
\hline keithel & SR & $30 \pm 6$ & $108 \pm 5$ & $128 \pm 5$ & $3270 \pm 798$ & $3870 \pm 918$ & $600 \pm 120$ \\
\hline \multirow[b]{2}{*}{ Kongba Bazaar } & $\mathrm{R}$ & $350 \pm 40$ & $88 \pm 5$ & $110 \pm 5$ & $31000 \pm 5270$ & $38700 \pm 6150$ & $7700 \pm 880$ \\
\hline & SR & $34 \pm 7$ & $110 \pm 5$ & $120 \pm 5$ & $3775 \pm 940$ & $4115 \pm 1010$ & $340 \pm 70$ \\
\hline \multirow[b]{2}{*}{ Pisum Keithel } & $\mathrm{R}$ & $225 \pm 30$ & $88 \pm 5$ & $108 \pm 5$ & $19950 \pm 3765$ & $24450 \pm 4365$ & $4500 \pm 600$ \\
\hline & SR & $27 \pm 5$ & $108 \pm 5$ & $118 \pm 5$ & $2941 \pm 675$ & $3211 \pm 725$ & $270 \pm 50$ \\
\hline \multirow[b]{2}{*}{ Jiri Bazaar } & $\mathrm{R}$ & $200 \pm 20$ & $88 \pm 5$ & $110 \pm 5$ & $17700 \pm 2760$ & $22100 \pm 3200$ & $4400 \pm 440$ \\
\hline & SR & $23 \pm 5$ & $110 \pm 5$ & $128 \pm 5$ & $2555 \pm 665$ & $2969 \pm 755$ & $414 \pm 90$ \\
\hline \multirow[b]{2}{*}{ Sekmai Bazaar } & $\mathrm{R}$ & $250 \pm 30$ & $88 \pm 5$ & $112 \pm 5$ & $22150 \pm 3890$ & $28150 \pm 4610$ & $6000 \pm 720$ \\
\hline & SR & $23 \pm 5$ & $112 \pm 5$ & $128 \pm 5$ & $2601 \pm 675$ & $2969 \pm 755$ & $368 \pm 80$ \\
\hline
\end{tabular}




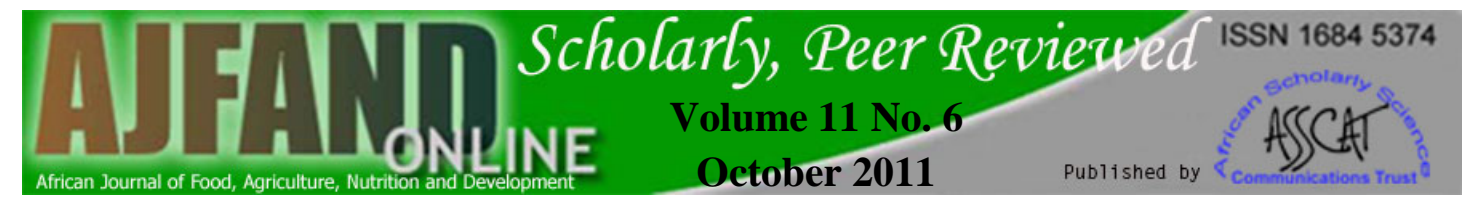

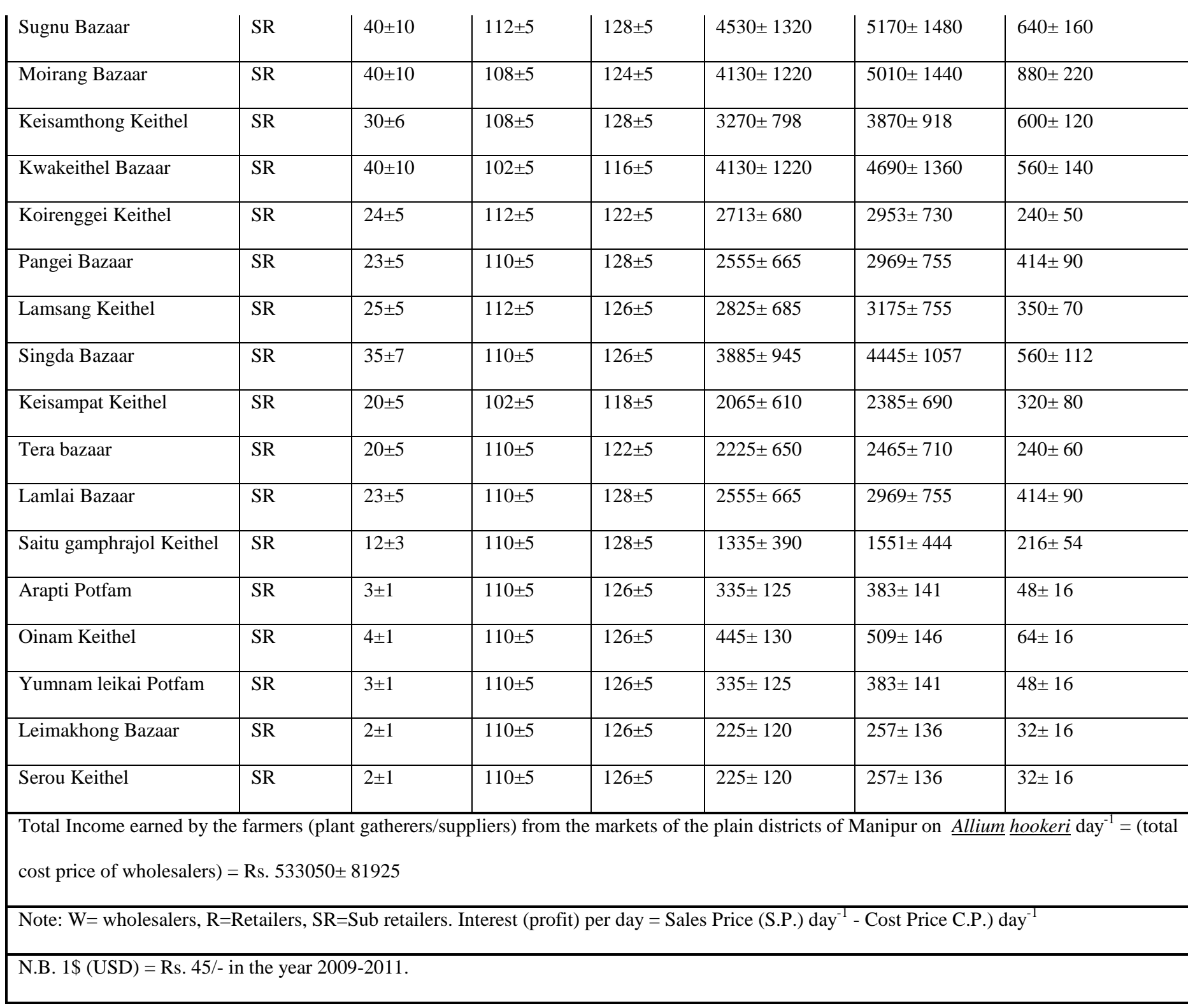




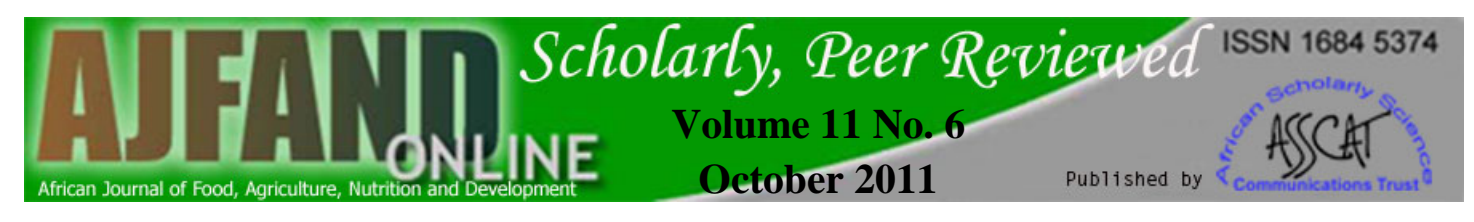

\begin{tabular}{|c|c|c|c|c|c|c|c|}
\hline \multicolumn{8}{|c|}{$\begin{array}{l}\text { Table 6: Daily Market scenario of } \underline{\text { Allium }} \underline{\text { hoc }} \\
\text { districts of Manipur in }(2009-2010)\end{array}$} \\
\hline Name of the market & $\begin{array}{l}\text { Category of } \\
\text { the Markets }\end{array}$ & $\begin{array}{l}\text { Quantity } \\
\text { Sold day }^{-1}\end{array}$ & $\begin{array}{l}\text { Cost price } \\
\text { in Rs. } \mathrm{Kg}^{-1}\end{array}$ & $\begin{array}{l}\text { Sale price } \\
\text { in } \mathrm{Rs} \mathrm{Kg}^{-1}\end{array}$ & $\begin{array}{l}\text { Total cost } \\
\text { price in Rs. }\end{array}$ & $\begin{array}{l}\text { Total sale } \\
\text { Price in Rs. }\end{array}$ & $\begin{array}{l}\text { Total Income } \\
\text { (profit) in Rs. } \\
\text { day }^{-1}\end{array}$ \\
\hline \multirow[b]{2}{*}{ Churachandpur Bazaar } & $\mathrm{R}$ & $300 \pm 50$ & $88 \pm 5$ & $112 \pm 5$ & $26650 \pm 5900$ & $33850 \pm 7100$ & $7200 \pm 1200$ \\
\hline & SR & $40 \pm 2$ & $112 \pm 5$ & $130 \pm 5$ & $4490 \pm 424$ & $5210 \pm 460$ & $720 \pm 36$ \\
\hline \multirow[b]{2}{*}{ Wino bazaar } & $\mathrm{R}$ & $300 \pm 50$ & $88 \pm 5$ & $112 \pm 5$ & $26650 \pm 5900$ & $33850 \pm 7100$ & $7200 \pm 1200$ \\
\hline & SR & $60 \pm 5$ & $112 \pm 5$ & $130 \pm 5$ & $6745 \pm 865$ & $7825 \pm 950$ & $1080 \pm 85$ \\
\hline Senapati Bazaar & SR'(VENDOR) & $50 \pm 5$ & $112 \pm 5$ & $130 \pm 5$ & $5625 \pm 810$ & $6525 \pm 900$ & $900 \pm 90$ \\
\hline Tamenglong Bazaar & SR'(VENDOR) & $20 \pm 2$ & $112 \pm 5$ & $130 \pm 5$ & $2250 \pm 324$ & $2610 \pm 360$ & $360 \pm 36$ \\
\hline Maram Bazaar & $\begin{array}{l}\text { SR' } \\
\text { (VENDOR) }\end{array}$ & $15 \pm 2$ & $112 \pm 5$ & $130 \pm 5$ & $1690 \pm 299$ & $1960 \pm 335$ & $270 \pm 36$ \\
\hline Mao Bazaar & SR'(VENDOR) & $20 \pm 2$ & $112 \pm 5$ & $130 \pm 5$ & $2250 \pm 324$ & $2610 \pm 360$ & $360 \pm 36$ \\
\hline Sapermina Keithel & SR'(VENDOR) & $40 \pm 2$ & $112 \pm 5$ & $130 \pm 5$ & $4490 \pm 424$ & $5210 \pm 460$ & $720 \pm 36$ \\
\hline None Bazaar & SR'(VENDOR) & $45 \pm 2$ & $112 \pm 5$ & $130 \pm 5$ & $5050 \pm 449$ & $5860 \pm 485$ & $810 \pm 36$ \\
\hline Yaingungpokpi Keithel & SR'(VENDOR) & $30 \pm 2$ & $112 \pm 5$ & $130 \pm 5$ & $3370 \pm 374$ & $3910 \pm 410$ & $540 \pm 36$ \\
\hline Chandel Bazaar & SR'(VENDOR) & $45 \pm 2$ & $112 \pm 5$ & $130 \pm 5$ & $5050 \pm 449$ & $5860 \pm 485$ & $810 \pm 36$ \\
\hline Kangpokpi Keithrl & SR'(VENDOR) & $8 \pm 2$ & $112 \pm 5$ & $130 \pm 5$ & $906 \pm 264$ & $1050 \pm 300$ & $144 \pm 36$ \\
\hline \multicolumn{8}{|c|}{$\begin{array}{l}\text { - Wholesalers in markets of hill districts and two of the markets have retailers and sub-retailers while the remaining was of } \\
\text { only small vendors (SR'). Plant collectors themselves sold the plant at retail price which in turn were sold at sub-retail } \\
\text { prices, but for the markets having only SR', collectors sold to vendors at sub-retail prices. }\end{array}$} \\
\hline \multicolumn{8}{|c|}{$\begin{array}{l}\text { - Total Income earned by the farmers (plant gatherers/suppliers) from the markets of the Hill districts of Manipur on } \underline{\text { Allium }} \underline{\text { hookeri }} \\
\text { day }^{-1}=\text { (sum of the cost price of the retailers + sum of the cost price of the sub-retail or vendors.) Rs. } 83981 \pm 15517\end{array}$} \\
\hline \multicolumn{8}{|c|}{ Note: $\mathrm{W}=$ wholesalers, $\mathrm{R}=$ Retailers, $\mathrm{SR}=$ Sub retailers. Interest (profit) per day = Sales Price (S.P.) - Cost Price C.P.) } \\
\hline
\end{tabular}




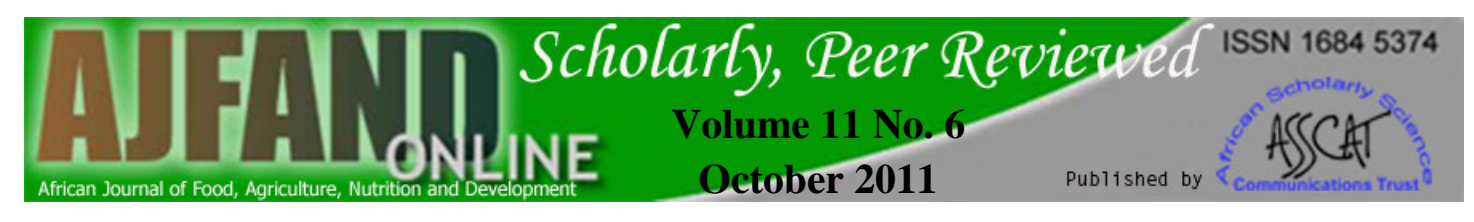

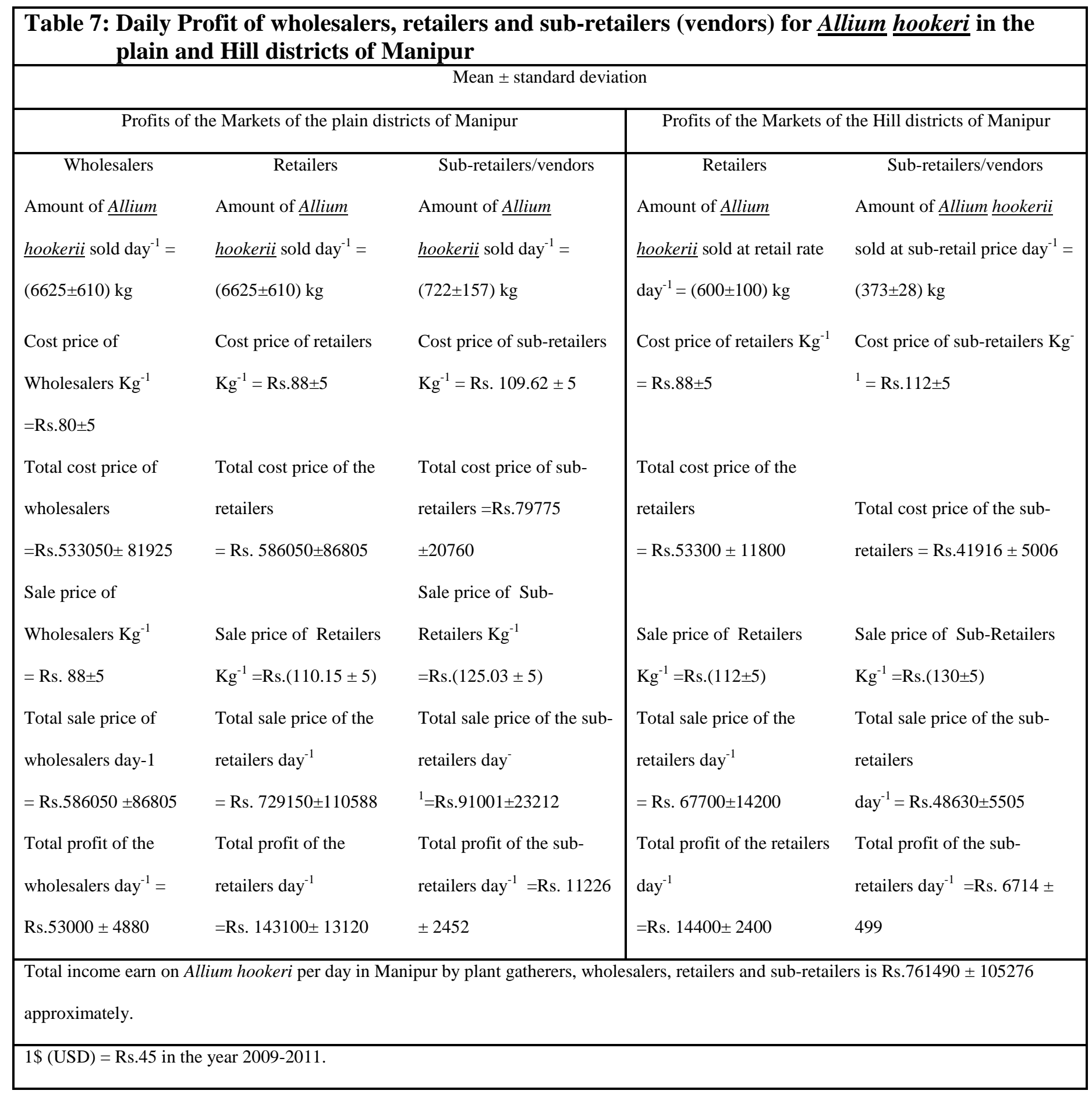




\section{REFERENCES}

1. Govt. of India. Ethnobiology in India - A Status Report for1994. Ministry of Environment and Forest, GOI, New Delhi, 1994.

2. Hooker JD Allium Hookeri. In: Flora of British India. Publisher Bishen Singh Mahendra Pal Singh, 23-A, New Connaught Place Dhera Dun, 1978. Vol. VI.: 341.

3. Sinha RK and S Sinha Ethnobiology (Role of Indigenous and Ethnic Societies in Biodiversity Conservation, Human Health Protection and Sustanable Development). In: Surabhi Publications, Jaipur. (Eds). Wild edible plants used by the ethnic people of Manipur. Naraina Industrial area, New Delhi-110028. Jagrit offset press, 2001: 48.

4. Keith HS Indigenous fermented food technologies for small-scale industries. In: Food and nutrition Bul. The U.N. Univ. press, 1985; 7(4): 1-10.

5. Francais $\mathbf{P}$ Improving nutrition through home gardening-Broadening the food base with indigenous plants. In: Information sheet 12, FAO corporate document repository, Agri. Dept. 2007.

6. Singh AJ Vegetable in Manipur. In: A. Ibochouba Singh, Arrow-head. poana bazar, Imphal, Manipur, India, Padma printers, 1996: 191.

7. Singh RP 1982, Geography of Manipur, National Book Trust, India, New Delhi.

8. Registered General of India. Census Report based on Language data for 2001. RGI, Census Dept. New Delhi, 2004: Series 15.

9. Registered General of India. Primary Census Abstract and special Table for SC and ST for 2001. Reg. Gen. of India, Census Dept. New Delhi, 2004:Series 15.

10. Registered General of India. Census Report based on Religion data for 2001. RGI, Census Dept. New Delhi, 2004: Series 15.

11. Devi LD Allium hookerii (Maroi Napakpi). In: Folklore Medicines of Ethnobiological Importance in Manipur. 1990. 1st Ed. Vol. I.

12. Dubois M, Gillis KA, Hamilton JK, Reber PA and F Smith A calorimetric method for the determination of sugars. Nature 1951; 186: 167-168.

13. Nelson $\mathbf{N}$ A Photometric Adaptaion of the Somogyi Method for determination of Glucose. J. Bio. Chem. 1994; 153: 375-380. 


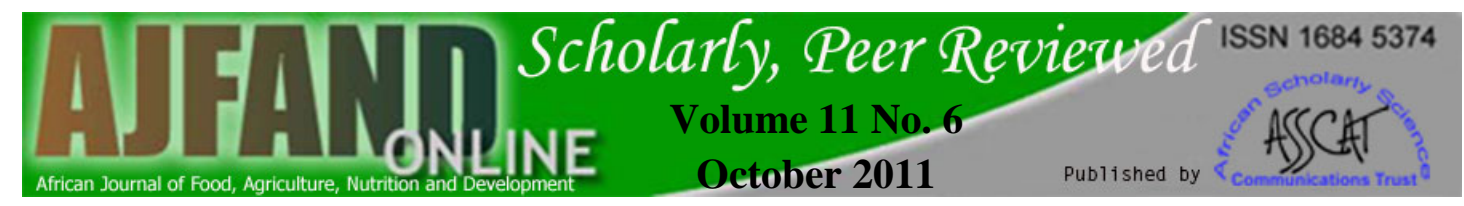

14. Malhotra SS and SK Sarkar Effects of Sulphur Dioxide on Sugar and Free Amino Acid Content of Pine Seedlings. Physiol. Plant. 1979;47:223-228.

15. Leslie HF and HJ Fisher Modern Food Analysis. Springer Verlag, New York. 1971: 16-17.

16. Moore S and WH Stein Photometric Method for use in the Chromatography of Amino Acids. J. Bot. Chem. 1948; 176: 367-388.

17. Stahl E Thin Layer Chromatography. New york, Academic Press, 1969.

18. Lang CA Simple Micro-determination of Kjeldahl in Biological Materials. Anal. Chem. 1958; 30: 1692-1694.

19. Roe JH Chemical Determination of Ascorbic, Dehydroascorbic and Diketogluconic Acids. Meth. Biochem. Anal. 1954; 1: 115-139.

20. Bray HG and WV Thorpe Analysis of Phenolic Compounds of Interest in Metabolism. Meth. Biochem. Anal. 1954; 1: 27-52.

21. Grunwald C Sterol Distribution in Intracellular Organelles isolated from tobacco leaves. Plant Physiol. 1970; 45: 663-666.

22. AOAC. Official Methods of Analysis. $14^{\text {th }} \mathrm{Ed}$. Association of Official Analytical Chemists, Washington D.C. 1965.

23. Talati S and P Shah Nutritional Studies On Fresh and Dehydrated Onion ( Allium Cepa Linn). Shodh, Samiksha aur Mulyankan (Intrnal. Re. Jr.), ISSN0974-2832 Vol. II, Issue-5 (Nov.08-Jan.09) 443-445.

24. Mari'n ER, Jensen RI, Krath BN, Kristensen M, Poulsen M, Cano MP, Moreno CS and LO Dragsted An Onion Byproduct Affects Plasma Lipids in Healthy Rats. J. Agric. Food Chem. 2010; 58: 5308-5314.

25. Rahman I and S Chung Dietary Polyphenols, Deacetylases and Chromatin Remodeling in Inflammation. World Rev Nutr Diet. Basel, Karger, 2010; 101: 84-94.

26. Racette SB, Lin X, Lefevre M, Spearie CA, Most MM, Ma L and RE Ostlund Jr Dose effects of dietary phytosterols on cholesterol metabolism: a controlled feeding study. Am J Clin Nutr 2010; 91: 32-8.

27. Timothy PC, Ash MM and AW Brown Cholesterol-lowering phytosterols: factors affecting their use and efficacy. Nutrition and Dietary Supplements. Dove Medical Press Ltd. 2010; 2: 59-72. 
28. Rossi L, Sacannab S and KP Velikov Cholesteric colloidal liquid crystals from phytosterol rod-like particles. Soft Matter, (C) The Royal Society of Chemistry 2011; 7: 64-67.

29. Richard E and Jr Ostlund Phytosterols in human nutrition. Annual Review of Nutrition 2002; 22( 533):549

30. Wu CP, Calcagno AM, Hladky SB, Ambudkar SV and MA Barrand Modulatory effects of plant phenols on human multidrug-resistance proteins 1 , 4 and 5 (ABCC1,4 and 5). FEBS Jr. 2005; 272: 4725-4740.

31. Visioli F, Borsani L and C Galli Diet and prevention of coronary heart disease: the potential role of phytochemicals. Cardiovascular Research 2000; 47: 421.

32. Normala H and MI Suhaimi Quantification of Total Phenolics in Different Parts of Pluchea indica (Less) Ethanolic and Water Extracts. Pertanika J. Sci. \& Technol. 2011; 19 (1): 19 - 24.

33. Mohamed OS, Said MM, Ali ZY, Atia HA and HS Mostafa Improving Effect of Dietary Oat Bran Supplementation on Oxidative Stress Induced by Hyperlipidemic Diet. Researcher, 2011; 3(2): 51-61.

34. Chen SC, Judd JT, Kramer M, Meijer GW, Clevidence BA and DJ Baer Phytosterol intake and dietary fat reduction are independent and additive in their ability to reduce plasma LDL Cholesterol. Lipids 2009; 44: 273-281.

35. Lu YC Study on the antimicrobial and antioxidation of Chinese leek. Asia University 2009;

dc.identifier.uri:item: http://asiair.asia.edu.tw/ir/handle/310904400/2908.Issu e Date: 2009-11-16T08:08:04Z Accessed: 20/04/2010.

or

http://scholar.google.co.in/scholar?hl=en\&q=Ethyl+acetate+extracts+of+Alliu $\underline{m}+$ hookeri+and+antimicrobial+activity $+\& b \operatorname{tnG}=$ Search\&as_sdt=0,5\&as_ylo= \&as vis $=1$ 